\title{
Effects of Exogenous Melatonin Supplementations on Some Elemental Contents in Anatolian Black Pine (Pinus nigra J.F. Arnold. subsp. pallasiana (Lamb.) Holmboe) Seedling Tissues
}

\author{
Esra Nurten Yer Çelik* \\ A multi-directional relationship may be conceivable between elements and \\ melatonin in sessile organisms. Melatonin is an important hormone that \\ helps regulate metabolism. This study investigated how different doses $(0$ \\ $\mu \mathrm{M} /$ control, $250 \mu \mathrm{M}, 500 \mu \mathrm{M}, 1000 \mu \mathrm{M}$, and $1500 \mu \mathrm{M}$ ) of exogenous \\ melatonin supplementations (EMS) affected the elemental contents in \\ Anatolian black pine (Pinus nigra Arnold. ssp. pallasiana (Lamb.) \\ Holmboe) seedling tissues (root, stem, and needle). Two different \\ application forms (root-dipping and needle-spraying) were selected in the \\ study. In the samples of seedling tissues, sodium (Na), potassium (K), \\ calcium $(\mathrm{Ca})$, iron $(\mathrm{Fe})$, aluminum $(\mathrm{Al})$, magnesium $(\mathrm{Mg}) / \mathrm{ppm}$; chrome \\ $(\mathrm{Cr})$, cobalt $(\mathrm{Co})$, copper $(\mathrm{Cu})$, manganese $(\mathrm{Mn})$, nickel (Ni), phosphorus \\ $(\mathrm{P})$, selenium $(\mathrm{Se})$, silicium $(\mathrm{Si})$, silver $(\mathrm{Ag})$, sulfur $(\mathrm{S})$, zinc $(\mathrm{Zn})$, and \\ molybdenum (Mo)/ppb were analyzed using inductively coupled plasma \\ optical emission spectroscopy (ICP-OES). Of the 18 elements examined, \\ there was a statistically significant difference $(p<0.05)$ between all \\ seedling tissues and different doses of EMS. The results show that EMS \\ may have the regulatory effect on seedling tissue element metabolism.
}

Keywords: Mineral element interaction; Exogenous melatonin; Root-dipping; Needle spraying; Anatolian black pine tissues

Contact information: Department of Forest Engineering, Kastamonu University, 37100, Kastamonu,

Turkey;

*Corresponding author: esranurtenyer@gmail.com

\section{INTRODUCTION}

According to the most recent data, 22.7 million ha of forested land covers approximately $29 \%$ of Turkey's territory. Productive forest areas account for approximately $58 \%$ of total forest areas, while non-productive forest areas account for approximately $42 \%$. Coniferous forests cover approximately 47\% (10.7 million ha) of the country's whole forest area (Anonymous 2019). Although Turkey has a great forest potential in terms of ecology, only $29 \%$ of its land has characteristics of forest due to anthropogenic and environmental effects (Atalay 2002). Black pine occupies a wide geographical distribution in the world. It is naturally distributed on three continents-Asia, Africa, and Europe-with five species (Mirov 1967). These are subsp. nigra, subsp. salzmannii, subsp. dalmatica, subsp. laricio, and subsp. pallasiana (Anonymous 2013). It is one of these five subspecies, with a range that includes the Balkans, Anatolia, Crimea, the Southern Carpathian Mountains, Cyprus, and Syria (Richardson 1998). Pinus nigra J.F. Arnold. subsp. pallasiana (Lamb.) Holmboe is known also as Anatolian Black Pine. It is one among the most common and economically important native primary tree species in Turkey (Atalay and Efe 2012). This subspecies has the third largest expansion area (4.3 
million ha) after oak (Quercus sp.) and red pine (Pinus brutia Ten.) among forest tree species in Turkey (Anonymous 2019). Anatolian black pine grows naturally throughout most of Turkey, with the exception of the Eastern Black Sea, Eastern, and South-eastern ecological regions (Atalay 2002; Öner and Eren 2008). Anatolian black pine is found in both pure and mixed forests in Turkey's coastal mountains, and it can also be found in steppe. Its naturally propagation within the vertical direction is between 700 and $2100 \mathrm{~m}$ (Matarac1 2002). Every year, approximately 100 million black pine seedlings are grown in Turkish forest nurseries to meet the demand for seedlings. It is the primary species for seedling propagation in the rate of approximately $22 \%$ afforestation carried out in Turkey (Anonymous 2019).

Reforestation is critical around the world, and Turkey has encouraged the planting of tree species in recent years. However, many trees die after outplanting, and failure rates rise within the first five years following establishment. Poor output in such cases may be due to low standards of careless planting or a scarcity of quality seed selection (Radoglou 1999). The quality of seedlings is used to assess the afforestation value and adaptation capacity of seedlings (Şimşek 1987; Avanoğlu et al. 2005). Even seedlings grown under optimum cultural practices and carefully handled are known to go into shock following transplanting. It is unlikely that transplant shock can be entirely eliminated. The damage to the root system during lifting and handling procedures may also be a significant factor. Plants are exposed to drying conditions at several stages during the process of lifting, handling, and transportation before planting (McCreary and Lippitt 2000). The root system of the seedlings accustomed to the afforestation of arid and semi-arid areas should be developed, and the stem / root ratio should be in favor of the root (Öner and Eren 2008). Considering that nutrient intake affects the growth of seedlings, a better understanding of the nutritional amount of elements to produce drought-resistant seedlings is needed. Planting quality is decided by characteristics of seedlings and might be assessed after planting, by detecting the elemental nutrient value of plants (Breoadley et al. 2012). Therefore, there is a need for natural substances to extend the afforestation value of seedlings and adaptation ability.

Melatonin (N-acetyl-5-methoxytryptamine) was discovered in 1958; it is a highly conserved biomolecule (Lerner et al. 1958). The existence of melatonin was discovered in plants in 1996. However, scientific studies on the effects of melatonin on plants have gained speed in the last decade (Arnao and Hernandez-Ruiz 2015). It is a multifunctional signal particle and plant growth regulator that is ubiquitous in various parts of plants (VanTassel et al. 2001a; Van-Tassel et al. 2001b; Debnath et al. 2019).

Melatonin has the potential to behave as a metal chelator due to its contents of a 5methoxyindole group and an N-ethylacetamide group with nitrogen and oxygen atoms. Melatonin's capacity to chelate metals was found to be concentration dependent (Limson et al. 1998; Gulcin et al. 2002). Clearly, the creation of complexes is influenced by the amount of metal ions, which varies between tissues, as well as melatonin concentrations. Melatonin, in addition to binding $\mathrm{Cu}^{2+}$, appears to protect against copper-mediated free radical damage via binding $\mathrm{Cu}^{+}$, according to electrochemical experiments. Melatonin forms compounds with lithium, potassium, sodium, and calcium (Lack et al. 2001). Melatonin appears to be an effective metal chelating agent based on these findings. Interestingly, the majority of research revealed that melatonin has the ability to bind metal ions, although a clear mechanism has yet to be discovered (Galijasevic 2017).

Melatonin is synthesized ubiquitously in plant organs (Park et al. 2012; Byeon et al. 2013; Byeon and Back 2014; Byeon et al. 2014; Wang et al. 2014; Nawaz et al. 2016). 
Different amounts of melatonin are found in various plant tissues/organs (Erland et al. 2015; Reiter et al. 2015). Melatonin is involved in multiple developmental processes in plants. Several studies have noted that melatonin is active in plants and is responsible for stimulating the growth of roots and shoots or preventing the growth of primary roots (Park and Back 2012) and encouraging lateral and adventitious rooting in different species (Murch et al. 2001; Hernández-Ruiz et al. 2005; Hernández-Ruiz and Arnao 2005), including governing the growth of roots and shoots (Tan et al. 2012).

Furthermore, melatonin activates the antioxidant system, scavenging ROS under stress, chelating heavy metal, and alleviating oxidative stress (Zhang et al. 2015; Yu et al. 2018; Yu et al. 2021). Hence, exogenous melatonin could be utilized as a bio-stimulator for the plants. Plant hormones such as melatonin are used in nascent forestry research, just as they are in other types of agriculture (Atik 2013).

The aim of this study is to investigate the interaction of exogenous melatonin supplements with the amounts of the elements. This study examined how different doses $(0 \mu \mathrm{M}$ /control, $250 \mu \mathrm{M}, 500 \mu \mathrm{M}, 1000 \mu \mathrm{M}$, and $1500 \mu \mathrm{M})$ of exogenous melatonin supplementations (EMS) affected the amount of elements in Anatolian black pine (Pinus nigra Arnold. ssp. pallasiana (Lamb.) Holmboe) seedling tissues (root, stem, and needle). Two different application forms (root-dipping and needle-spraying) were examined to determine which application form was more effective. Morphological, physiological, and genetic measurements of the seedling quality characteristics will be a different subject and will be studied in the future. This study provides new insights into the health of forest tree seedlings and the use of EMS.

\section{EXPERIMENTAL}

\section{Research Area}

The field experiment was conducted in 2019 (March to November) at Tosya, a city on the west coast of the Black Sea Region in Turkey and of one of the biggest towns of Kastamonu province (Fig. 1). The working field location was carried out in 76.8 ha afforestation land at the Kastamonu Regional Directorate of Forestry, Tosya Property directorate, chief Akseki Business, Karasapaca by village F32 / D4 section number (Turkey forest number 230/231). The location of the study is $412^{\prime} 55.05^{\prime \prime} \mathrm{N}, 344^{\prime} 16.45^{\prime \prime} \mathrm{E}$. The study area is located in the south, at an altitude of $910 \mathrm{~m}$, average rainfall of $4.775 \mathrm{~mm}$, average annual temperature of $41.5^{\circ} \mathrm{C}$, a slope range $31 \%$ to $60 \%$, and a soil structure of sandy clay. A total of 34,500 black pine seedlings were planted (with $1.5 \mathrm{~m}$ intervals) in the work field within the scope of the Soil Conservation Implementation Project. 

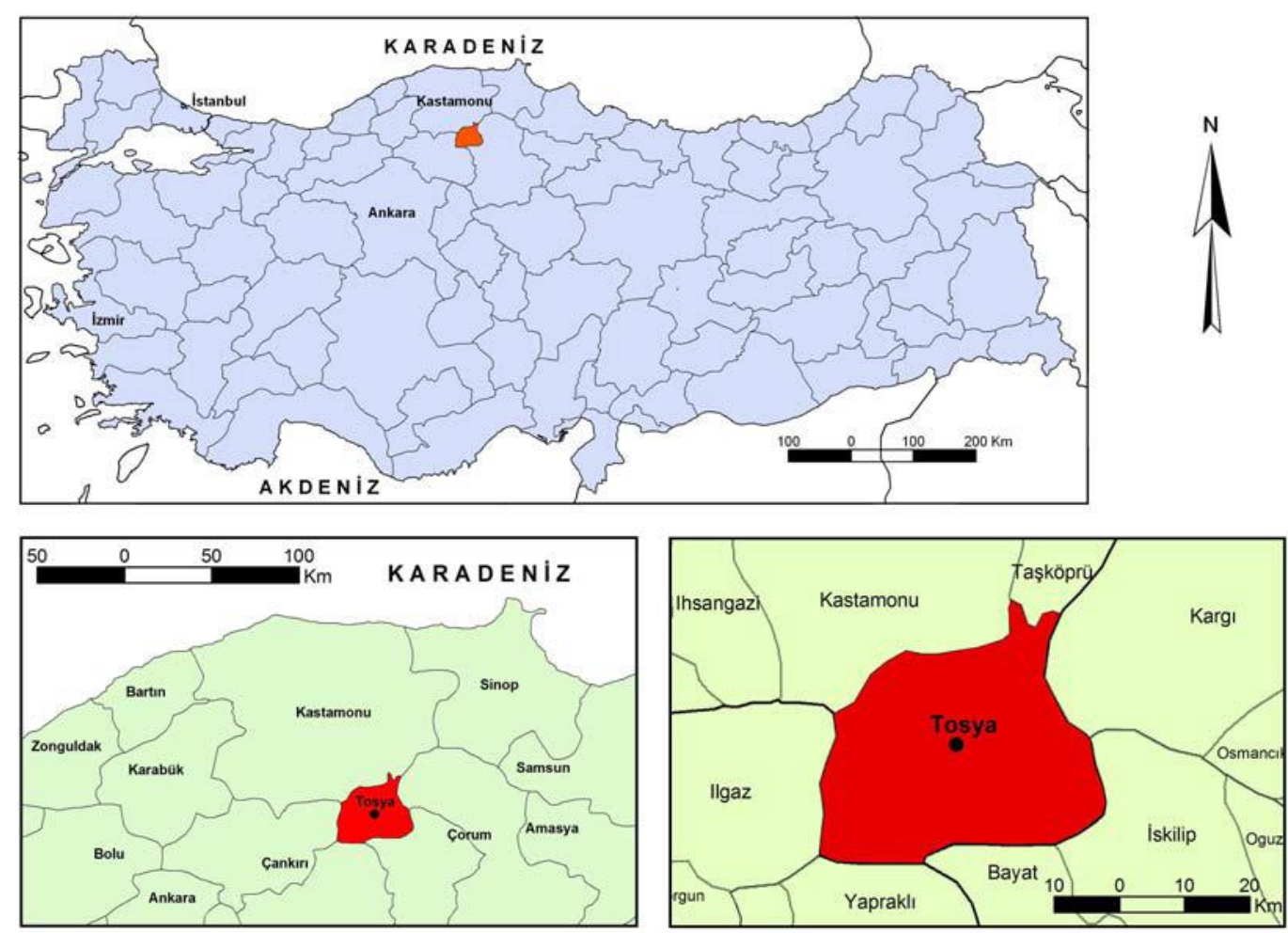

Fig. 1. Geographical location of Tosya district where the samples were taken in Karasapaca afforestation area (Taş 2006)

\section{Experimental Designs, Preparation of Plant Samples and Melatonin Treatments}

In this study, melatonin was purchased from Sigma-Alrich (St. Louis, MO, USA) and was dissolved in $200 \mu \mathrm{L}$ ethanol followed by dilution with water (ethanol: water v/v = 1/10.000). Five different EMS doses $(0 \mu \mathrm{M} /$ control, $250 \mu \mathrm{M}, 500 \mu \mathrm{M}, 1000 \mu \mathrm{M}$, and 1500 $\mu \mathrm{M}$ ) and 2 different application forms (root-dipping and needle-spraying) were applied to a total of 60 seedlings with 3 replications. In total, 10 seedlings were removed from each repeat (3x10). The root, stem, and needle tissues of 10 seedlings with 3 replicates removed were combined separately and used in element analysis. Materials collected at root, stem, and needle tissues were examined in the analysis. In the first application method of the melatonin substance, at the beginning of the vegetation period, the roots of the seedlings were soaked in melatonin for $30 \mathrm{~min}$ (root-dipping) before planting. For the second application method, melatonin substance was applied by spraying only to the needles of the seedlings. The samples were collected towards the end of the vegetation season at the end of November.

\section{Laboratory Pretreatment and Mineral Element Analysis}

Plant samples were made homogeneous using a mechanical grinder (Fritsch P- 15, Germany). Two grams of the dried samples were placed in $10 \mathrm{~mL}$ of concentrated $\mathrm{HNO}_{3}$ at room temperature for $24 \mathrm{~h}$ and then burned (at $180{ }^{\circ} \mathrm{C}$ ) using a CEM Mars 6 Microwave Reaction System (CEM Corporation, Matthews, NC, USA). Distilled water was added to the solution obtained from the filtrate. Element analysis was performed to determine the concentration of $\mathrm{Na}, \mathrm{K}, \mathrm{Ca}, \mathrm{Fe}, \mathrm{Al}, \mathrm{Mg}$ (ppm) / Cr, Co, Cu, Mn, Ni, P, Se, $\mathrm{Si}, \mathrm{Ag}, \mathrm{S}, \mathrm{Zn}$, and Mo (ppb) by inductively coupled plasma optical emission spectroscopy 
(ICP-OES; model Spectroblue FMX36, Spectro, Germany), using the Spectro smart analyzer software.

\section{Statistical Analyses}

The ICP-OES data obtained were evaluated with SPSS software (IBM, Armonk, NY, USA). For normality, the Shapiro-Wilk test was performed within each group and between two groups. Nonparametric tests (Kruskal-Wallis test) were applied as statistical tools to treat the data. When Kruskal-Wallis was tested, $\mathrm{p}<0.05$ was found for a statistically significant element. The difference between two independent universes was determined by the Mann-Whitney U test with the Bonferroni's correction.

\section{RESULTS AND DISCUSSION}

To investigate the effects of the amount of EMS, various elements were measured. The elements of potassium, copper, nickel, selenium, silicium, and silver were significantly different $(\mathrm{p}<0.05)$ between the two different application methods (root-dipping and needlespraying) of melatonin. However, there was no significant difference $(\mathrm{p}<0.05)$ in sodium, calcium, iron, aluminum, magnesium, cadmium, chromium, cobalt, manganese, phosphorus, sulfur, zinc, and molybdenum.

Compared with the control group, root application (dipping) of melatonin caused a significant difference in potassium, copper, selenium, silicium, and silver. Spray application caused a significant difference in calcium, copper, nickel, selenium, silicium, and silver, according to Bonferroni's correction. Compared with the control group, statistically, the $\mathrm{K}$ element in the direct root-dipping of melatonin material and the $\mathrm{Ni}$ element in the direct needle-spraying made a difference between the application groups. Melatonin inhibits the operation of large conductance calcium-activated potassium channels; it blocks endothelial potassium channels to minimize flow-induced nitric oxide release (Geary et al. 1998).

The 18 elements investigated made a statistically significant difference $(\mathrm{p}<0.05)$ in all sapling tissues (root, needle, stem). These results are similar to those in the literature (Balzer and Hardeland 1996; Van-Tassel and O'Neill 2001a; Hernández-Ruiz et al. 2004; Arnao and Hernandez-Ruiz 2006; Ye et al. 2017).

When the application of melatonin substance in only different dose groups compared to the control group was evaluated, there was no significant difference $(\mathrm{p}<0.05)$ between sodium, iron, aluminum, magnesium, chromium, cobalt, manganese, nickel, and sulfur. However, a significant difference $(\mathrm{p}<0.05)$ was found in the potassium, calcium, cadmium, copper, phosphorus, selenium, silicium, silver, zinc, and molybdenum (Fig. 2).

As the impact of melatonin on the elements was examined, it was seen that $500 \mu \mathrm{M}$ and $1000 \mu \mathrm{M}$ doses of melatonin resulted in an increase in the amount of the elements compared to the control group $(0 \mu \mathrm{M})$. When the statistical results were evaluated, it was more accurate to determine use of the low and middle dose.

Zhang J. et al. (2017) noted that high concentrations of melatonin (100 and 200 $\mathrm{mM}$ ) had an opposite effect and even decreased root growth in seedlings. Similar results were obtained in other studies (Chen et al. 2009; Sarropoulou et al. 2012; Wang et al. 2016; Marta et al. 2016; Sharif et al. 2018; Chen et al. 2020). As a result, several studies have shown that utilizing EMS in plants has an impact on the amount of elements present. 


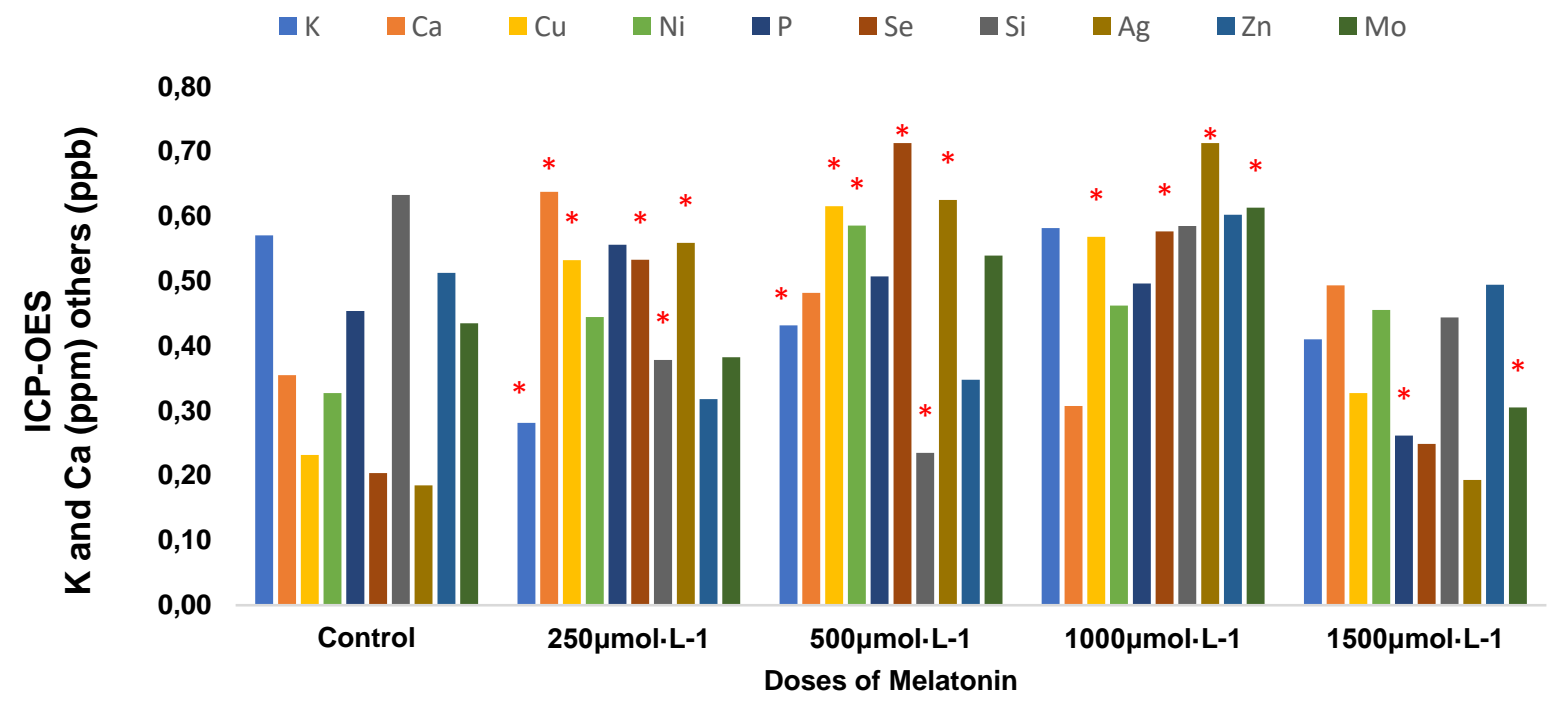

Fig. 2. Comparison of the elements that are meaningful only with respect to the dose compared with the control group. * Statistically different from the control group according to Bonferroni's correction

The interaction of the melatonin substance with 4 different doses and 2 different administration forms (root-dipping / needle-spraying) was compared with the control group. While there was a significant difference $(\mathrm{p}<0.05)$ in the elements of potassium, calcium, copper, phosphorus, selenium, silicium, silver, zinc, and molybdenum, no significant difference was found in the elements sodium, iron, aluminum, magnesium, chromium, cobalt, manganese, nickel, and sulfur (Table 1). 
Table 1. Change in Macro/Micro Elements according to Different Melatonin Treatments (4 doses+control (Cont) and Method of Administration [root-dipping (Dip) + Needle-Spraying (Spray)]

\begin{tabular}{|c|c|c|c|c|c|c|c|c|c|c|}
\hline \multirow{3}{*}{$\begin{array}{c}\text { Macro } \\
\text { /Micro } \\
\text { Element }\end{array}$} & \multirow{2}{*}{ Control } & \multicolumn{2}{|c|}{$250 \mu M$} & \multicolumn{2}{|c|}{$500 \mu \mathrm{M}$} & \multicolumn{2}{|c|}{$1000 \mu \mathrm{M}$} & \multicolumn{2}{|c|}{$1500 \mu \mathrm{M}$} & \multirow{3}{*}{ H / P Values } \\
\hline & & Dip & Spray & Dip & Spray & Dip & Spray & Dip & Spray & \\
\hline & \multicolumn{9}{|c|}{ Means } & \\
\hline $\mathrm{Na}$ (ppm) & 45.50 & 36.83 & 55.61 & 42.89 & 46.28 & 58.50 & 42.89 & 33.50 & 47.50 & $6.709^{\text {/ns }}$ \\
\hline K (ppm) & 57.06 & 27.00 & 29.22 & 48.33 & 38.00 & 53.11 & 63.22 & 24.44 & 57.56 & $25.047^{\star \star}$ \\
\hline Ca (ppm) & 35.50 & 51.78 & 75.78 & 33.11 & 63.22 & 42.22 & 19.22 & 52.67 & 46.00 & $31.342^{* * *}$ \\
\hline Fe (ppm) & 37.50 & 38.06 & 39.00 & 54.00 & 60.50 & 53.44 & 40.89 & 34.11 & 60.00 & $12.492^{\text {/ns }}$ \\
\hline Al (ppm) & 41.50 & 38.00 & 41.00 & 53.00 & 56.00 & 52.89 & 44.00 & 28.00 & 59.11 & $10.859^{\text {/ns }}$ \\
\hline Mg (ppm) & 39.28 & 41.00 & 40.44 & 50.67 & 53.67 & 52.22 & 38.11 & 39.78 & 60.56 & $7.594^{\text {/ns }}$ \\
\hline $\mathrm{Cr}$ (ppb) & 43.50 & 43.00 & 41.00 & 46.00 & 58.00 & 52.22 & 42.00 & 32.00 & 53.78 & $6.583^{\text {ns }}$ \\
\hline Co (ppb) & 36.28 & 38.00 & 38.44 & 54.89 & 58.11 & 53.67 & 43.67 & 36.33 & 59.33 & $11.457^{\text {/ns }}$ \\
\hline Cu (ppb) & 23.17 & 53.33 & 53.11 & 60.22 & 62.89 & 57.78 & 55.89 & 13.44 & 52.00 & $39.094^{\star \star \star}$ \\
\hline Mn (ppb) & 46.61 & 37.22 & 32.78 & 56.00 & 54.00 & 45.00 & 51.78 & 34.00 & 51.00 & $8.144^{\text {/ns }}$ \\
\hline $\mathrm{Ni} \quad$ (ppb) & 32.72 & 45.89 & 43.00 & 52.11 & 65.00 & 50.33 & 42.11 & 33.00 & 58.11 & $14.599^{\text {/ns }}$ \\
\hline P (ppb) & 45.39 & 53.33 & 57.89 & 45.00 & 56.44 & 55.22 & 44.00 & 14.22 & 38.11 & 19.314 * \\
\hline Se (ppb) & 20.39 & 55.00 & 51.56 & 70.78 & 71.78 & 67.44 & 47.89 & 5.22 & 44.56 & $6.671^{\star \star \star}$ \\
\hline Si (ppb) & 63.28 & 28.67 & 47.00 & 21.67 & 25.33 & 72.89 & 44.11 & 32.78 & 56.00 & $38.464^{\star \star \star}$ \\
\hline Ag (ppb) & 18.50 & 56.78 & 55.00 & 59.89 & 65.11 & 76.33 & 66.22 & 5.00 & 33.67 & $71.647^{\star \star \star}$ \\
\hline S (ppb) & 47.28 & 46.11 & 54.11 & 32.89 & 59.67 & 48.33 & 51.33 & 23.00 & 45.00 & $13.045^{\text {/ns }}$ \\
\hline $\mathrm{Zn} \quad$ (ppb) & 51.28 & 33.56 & 30.00 & 35.11 & 34.44 & 61.44 & 59.00 & 27.89 & 71.00 & $27.387^{\star \star}$ \\
\hline Mo (ppb) & 43.50 & 46.00 & 30.50 & 48.11 & 59.72 & 72.67 & 50.00 & 30.50 & 30.50 & $30.931^{* \star *}$ \\
\hline
\end{tabular}


Thus, different forms of application of exogenous melatonin were found to have different effects on the plant's melatonin absorption. Similar outcomes have been obtained previously. Melatonin-induced changes in plant growth and tissues system architecture may be due to a signaling mechanism similar to that of mineral nutrients (Dawood and ElAwadi, 2015; Li et al. 2016; Zhang R. et al. 2017; Sharif et al. 2018).

When the dual interactions between the examined seedling tissues (root, needle, stem) and different dose groups of EMS were determined, there were significant differences $(\mathrm{p}<0.05)$ in all elements (Fig. 3; Fig. 4).

Compared to the control group, the amounts of the metal elements calcium, nickel, copper, selenium, and silver analyzed in the root, needle, and stem tissues of the $250 \mu \mathrm{M}$ dose application group were increased. Amounts of aluminum, iron, magnesium, cobalt, copper, selenium, silver, nickel, and calcium in the $500 \mu \mathrm{M}$ dose application group, and copper, selenium, and silver amounts of elements in $1.000 \mu \mathrm{M}$ dose application group were also increased compared to the control group (Fig. 3; Fig. 4).

Compared to the control group, the amount of sodium analyzed in the root and needle tissue was increased in the 250 and $500 \mu \mathrm{M}$ doses application groups; the analyzed amount of chromium in the $500 \mu \mathrm{M}$ dose application group and those of potassium, sodium, zinc, molybdenum, and chromium in the $1000 \mu \mathrm{M}$ dose application group were also elevated (Fig. 3; Fig. 4). The amount of lead element analyzed on root and stem tissue was increased in 250,500 , and $1000 \mu \mathrm{M}$ doses application groups compared with the control group (Fig. 4). The amount of manganese analyzed on the needle and body tissue was increased in the $500 \mu \mathrm{M}$ dose application group compared with the control group (Fig 3). The amounts of silicon and sulfur, which were analyzed on the body tissue were increased in the $1000 \mu \mathrm{M}$ dose application group compared to the control group (Fig. 4).

Figures 3 and 4 show that the value of the EMS is revealed by the increases in macro/micro elements responsible for the realization of plant metabolic activities. Likewise, it increased the amount of macro/micro elements that help maintain plant physiological processes. Melatonin has an important modulating influence on the mineral element composition of forest tree plants. Many studies have reported that melatonin functions in the binding, regulation, stimulation, amelioration, and enhancement of elements (Posmyk et al. 2008; Erdal and Dumlupinar 2011; Tan et al. 2012; Turk and Erdal 2015; Aguilera et al. 2015; Dawood and El-Awadi 2015; Li et al. 2016; Zhang J. et al. 2017; Zhang R. et al. 2017).

To sum up, the present study showed that exogenous melatonin supplementations applied to improve planting quality in forest trees have an important effect on the macro/micro amount of elements in the plant. However, more research is needed to prove melatonin's ability to promote plant development and quality seedlings, including experimental proof of the formed complex. The exogenous application of melatonin in forestry may be a new frontier to be explored. 

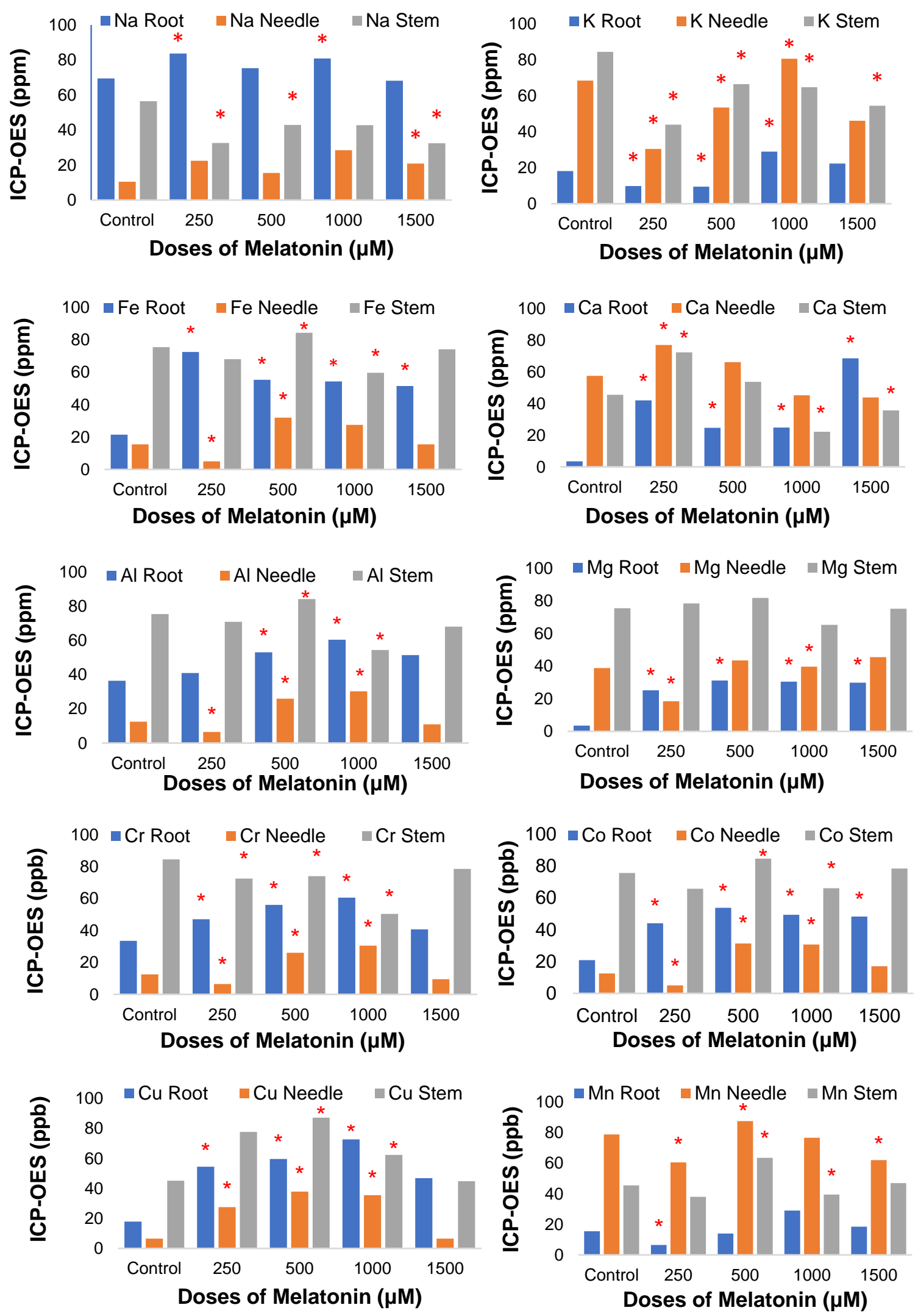

Fig. 3. Comparison of the different melatonin treatments and various seedling tissue from the different macro/micro elements

* Statistically different from the control group according to Bonferroni's correction. 

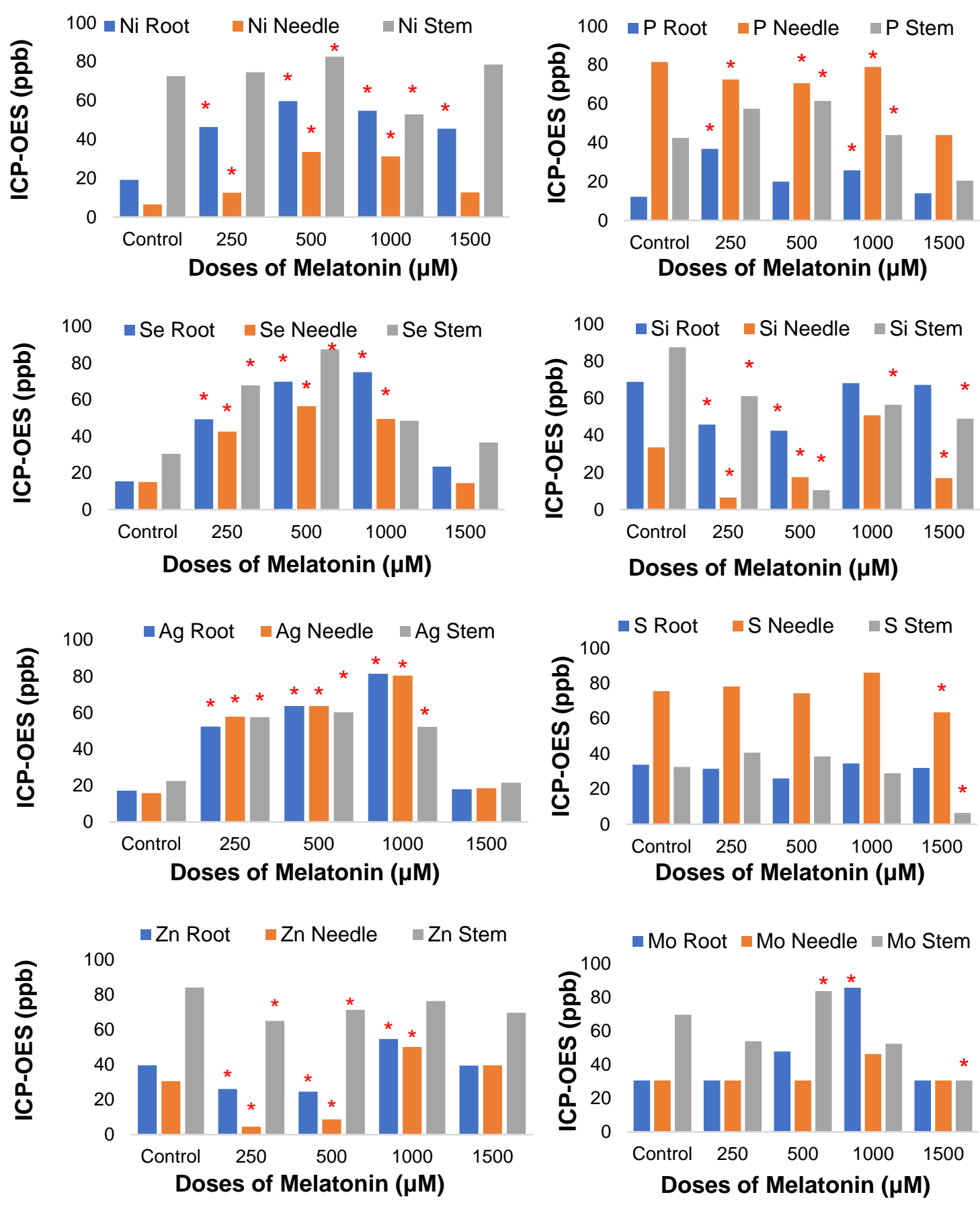

Fig. 4. Comparison of the different melatonin treatments and various seedling tissue from the different macro/micro elements

* Statistically different from the control group according to Bonferroni's correction.

\section{CONCLUSIONS}

1. High dose applications of exogenous melatonin supplementations (EMS) inhibited the elemental amounts of some macro / micro components in the wood tissue.

2. Different doses of EMS caused variable mobility in different tissues of the plant in 
terms of macro / micro amount of elements.

3. EMS needle-spraying applications of seedling had a greater impact on macro / micro amount of elements the control group.

\section{ACKNOWLEDGMENTS}

Funding support from the Kastamonu University (Scientific Research Project Foundation, KÜ-HIZDES/2019-09 Kastamonu, Turkey) is gratefully acknowledged. I also thank the editor-in chief and the anonymous reviewers for their valuable suggestions.

\section{REFERENCES CITED}

Aguilera, Y., Herrera, T., Liébana, R., Rebollo-Hernanz, M., Sanchez-Puelles, C., and Martín-Cabrejas, M. A. (2015). "Impact of melatonin enrichment during germination of legumes on bioactive compounds and antioxidant activity," Journal of Agricultural and Food Chemistry 63(36), 7967-7974. DOI: 10.1021/acs.jafc.5b03128

Anonymous (2013). Botanica, Random House Press, (Gordon Cheers) Press, NSW Australia, pp. 681.

Anonymous (2019). Republic of Turkey Ministry of Forestry and Water Affairs, General Directorate of Forestry, Ankara, Turkey, (http://www.ogm. gov.tr), Accessed March 4, 2019.

Arnao, M. B., and Hernández-Ruiz, J. (2006). "The physiological function of melatonin in plants," Plant Signaling \& Behavior 1(3), 89-95. DOI: 10.4161/psb.1.3.2640

Arnao, M. B, and Hernandez-Ruiz, J. (2015). "Functions of melatonin in plants: A review," Journal of Pineal Research 59, 133-150. DOI: 10.1111/jpi.12253

Atalay, İ. (2002). Ecoregions of Turkey (Publication No. 163), Ministry of Forestry, İzmir, Turkey.

Atalay, İ., and Efe, R. (2012). "Ecological attributes and distribution of Anatolian black pine [Pinus nigra Arnold. subsp. pallasiana Lamb. (Holmboe)] in Turkey," Journal of Environmental Biology (JEB) 33, 509-519.

Atik, A. (2013). "Effect of different concentrations of effective microorganisms (Baikal EM1) on the root collar diameter and height growth in the seedlings of Anatolian black pine [Pinus nigra Arnold. subsp. pallasiana Lamb. (Holmboe)]," Journal of Food, Agriculture \& Environment (JFAE), 11(2),1300-1304.

Avanoğlu, B., Ayan, S., Demircioğlu, N., and Sivacioğlu, A. (2005). "Evaluation of two years old seedlings of the Anatolian black pine (Pinus nigra Arnold. subsp. pallasiana (Lamb.) Holmboe.) raised in Kastamonu-Taskopru Forest Nursery as to TSI quality classification," Journal of Engineering and Natural Sciences 5, 73-83.

Breoadley, M., Brown, P., Cakmak, I., Rengel, Z., and Zhao, F. (2012). "Function of nutrients: micronutrients," In: Marschner's Mineral Nutrition of Higher Plants $\left(3^{\text {rd }}\right.$ ed.), P. Marshner (ed.), Academic Press Elsevier, London, UK, p.191-248. DOI: 10.1016/B978-0-12-384905-2.00007-8

Byeon, Y., and Back, K. (2014). "Melatonin synthesis in rice seedlings in vivo is enhanced at high temperatures and under dark conditions due to increased serotonin $\mathrm{N}$-acetyltransferase and $\mathrm{N}$-acetylserotonin methyltransferase activities," Journal of Pineal Research 56, 189-195. DOI: 10.1111/jpi.12111 
Byeon, Y., Lee, K., and Park, Y. I. (2013). "Molecular cloning and functional analysis of serotonin N-acetyltransferase from the Cyanobacterium synechocystis sp. PCC 6803," Journal of Pineal Research 55, 371-376. DOI: 10.1111/jpi.12080

Byeon, Y., Lee, H. Y., Lee, K., Park, S., and Back, K. (2014). "Cellular localization and kinetics of the rice melatonin biosynthetic enzymes SNAT and ASMT," Journal of Pineal Research 56, 107-114. DOI: 10.1111/jpi.12103

Chen, Q., Qi, W. B., Reiter, R. J., Wei, W., and Wang, B. M. (2009). "Exogenously applied melatonin stimulates root growth and raises endogenous indoleacetic acid in roots of etiolated seedlings of Brassica juncea," Journal of Plant Physiology 166, 324-328.

Chen, L., Liu, L., Lu, B., Ma, T., Jiang, D., Li, J., Zhang, K., Sun, H., Zhang, Y., Bai, Z., et al. (2020). "Exogenous melatonin promotes seed germination and osmotic regulation under salt stress in cotton (Gossypium hirsutum L.)," Plos One 15(1), e0228241. DOI: $10.1371 /$ journal.pone.0228241

Dawood, M. G., and El-Awadi, M. E. (2015). "Alleviation of salinity stress on Vicia faba L. plants via seed priming with melatonin," Acta Biológica Colombiana 20, 223-235.

Debnath, B., Islam, W., Li, M., Sun, Y., Lu, X., Mitra, S., Hussain, M., Liu, S., and Qiu, D. (2019). "Melatonin mediates enhancement of stress tolerance in plants," International Journal of Molecular Sciences 20, no. 5: 1040. DOI: 10.3390/ijms20051040

Erland, L. A., Murch, S. J., Reiter, R. J., and Saxena, P. K. (2015). “A new balancing act: The many roles of melatonin and serotonin in plant growth and development," Plant Signaling \& Behavior 10, e1096469.

Galijasevic, S. (2017). "Many roles of melatonin: Diversity and complexity of reaction pathways," Bulletin of the Chemists and Technologists of Bosnia and Herzegovina 48, 51-58.

Geary, G. G., Duckles, S. P., and Krause, D. N. (1998). "Effect of melatonin in the rat tail artery: Role of potassium channels and endothelial factors," British Journal of Pharmacology 123, 1533-1540.

Gulcin, I., Buyukokuroglu M. E., Oktay M., and Kufrevioglu O. I. (2002). "On the in vitro antioxidant properties of melatonin," Journal of Pineal Research. 33, 167-171.

Hernández-Ruiz, J., Cano, A., and Arnao, M. B. (2004). "Melatonin: A growthstimulating compound present in lupin tissues," Planta 220(1), 140-144. DOI: DOI: 10.1007/s00425-004-1317-3

Hernández-Ruiz, J., Cano, A., and Arnao, M. B. (2005). "Melatonin acts as a growthstimulating compound in some monocot species," Journal of Pineal Research 39, 137-142.

Hernández-Ruiz, J., and Arnao, M. B. (2008). "Melatonin stimulates the expansion of etiolated lupin cotyledons," Plant Growth Regulation 55, 29-34.

Lack, B., Daya S., and Nyokong, T. (2001). "Interaction of serotonin and melatonin with sodium, potassium, calcium, lithium and aluminium," Journal of Pineal Research 31 (2), 102-108.

Lerner, A. B., Case, J. D., Takahashi, Y., Lee, Y., and Mori, W. (1958). "Isolation of melatonin, a pineal gland factor that lightens melanocytes," Journal of the American Chemical Society 8, 2587.

Li, C., Liang, B., Chang, C., Wei, Z., Zhou, S., and Ma, F. (2016). "Exogenous melatonin improved potassium content in Malus under different stress conditions," Journal of Pineal Research 61, 218-229. DOI: 10.1111/jpi.12342 
Li, M. Q., Hasan, M. K., Li, C. X., Ahammed, G. J., Xia, X. J., Shi, K., Zhou, Y. H., Reiter, R. J., Yu, J. Q., Xu, M. X., and Zhou, J. (2016). "Melatonin mediates selenium-induced tolerance to cadmium stress in tomato plants," Journal of Pineal Research 61(3), 291-302. DOI: 10.1111/jpi.12346

Li, X., Wei, J. P., Scott, E. R., Liu, J. W., Guo, S., Li, Y., Zhang, L., and Han, W. Y. (2018). "Exogenous melatonin alleviates cold stress by promoting antioxidant defense and redox homeostasis in Camellia sinensis L.," Molecules (Switzerland), 23(1), 165. DOI:10.3390/molecules23010165.

Limson, J., Tebello N., and Oaya S. (1998). "The interaction of melatonin and its precursors with aluminium, cadmium, copper, iron, lead, and zinc: An adsorptive voltammetric study," Journal of Pineal Research 24(1), 15-21. https://doi.org/10.1111/j.1600-079x.1998.tb00361.x

Matarac1, T. (2002). Trees, Tema Publications, İstanbul.

Marta, B., Szafrańska, K., and Posmyk, M. M. (2016). "Exogenous melatonin improves antioxidant defense in cucumber seeds (Cucumis sativus L.) germinated under chilling stress," Frontiers in Plant Science 7, 575. DOI: 10.3389/fpls.2016.00575

McCreary, D. D., and Lippitt, L. (2000). "Blue oak mini-plug transplants: How they compare to standard bareroot and container stock," Native Plants Journal 1, 84-89.

Mirov, N. T. (1967). The Genus Pinus, Ronald Press, New York.

Murch, S., Campbell, S. S. B., and Saxena, P. K. (2001). "The role of serotonin and melatonin in plant morphogenesis. Regulation of auxin-induced root organogenesis in in vitro-cultured explants of Hypericum perforatum L," In Vitro Cellular \& Developmental Biology - Plant 37, 786-793. DOI: 10.1007/s11627-001-0130-y

Nawaz, M. A., Huang, Y., Bie, Z., Ahmed, W., Reiter, R. J., Niu, M., and Hameed, S. (2016). "Melatonin: Current status and future perspectives in plant science," Frontiers in Plant Science 6, 1230.

Öner N., and Eren, F. (2008). "The comparisons between root collar diameter and height growth of pine (Pinus nigra Arnold.) and Scots pine (Pinus sylvestris L.) seedlings in Bolu Forest Nursery," Journal of Applied Biological Sciences 2, 7-12.

Park, S., Lee, K., Kim, Y. S., and Back, K. (2012). "Tryptamine 5-hydroxylase-deficient Sekiguchi rice induces synthesis of 5-hydroxytryptophan and N-acetyltryptamine but decreases melatonin biosynthesis during senescence process of detached leaves," Journal of Pineal Research 52, 211-216. DOI: 10.1111/j.1600079X.2011.00930.X

Park, S., and Back, K. (2012). "Melatonin promotes seminal root elongation and root growth in transgenic rice after germination," Journal of Pineal Research 53, 385-389.

Posmyk, M. M., Kuran, H., Marciniak, K., and Janas, K. M. (2008). "Presowing seed treatment with melatonin protects red cabbage seedlings against toxic copper ion concentrations," Journal of Pineal Research 45, 24-31.

Radoglou, K. M. (1999). "Effect of environmental stress on planting stock and field performance," in: Proceedings of the National Forestry Conference: Planting Stock of Woody Species, Thessaloniki, Greece, pp. 15-26 (in Greek).

Reiter, R. J., Tan, D. X., Zhou, Z., Cruz, M. H., Fuentes-Broto, L., and Galano, A. (2015). "Phytomelatonin: Assisting plants to survive and thrive," Molecules (Basel, Switzerland), 20(4), 7396-7437. DOI: 10.3390/molecules20047396

Richardson, D. M. (1998). Ecology and Biogeography of Pinus, Cambridge University Press, Cambridge, UK.

Sarropoulou, V. N., Therios, I. N., and Dimassi-Theriou, K. N. (2012). "Melatonin 
promotes adventitious root regeneration in in vitro shoot tip explants of the commercial sweet cherry rootstocks cab-6p (Prunus cerasus L.), 'Gisela 6' ( $P$. cerasus_P. canescens), and mxm 60 (P. avium_P. mahaleb),' Journal of Pineal Research 52, 38-46.

Sharif, R., Xie, C., Zhang, H., Arnao, M. B., Ali, M., Ali, Q., Muhammad, I., Shalmani, A., Nawaz, M. A., Chen, P., and Li, Y. (2018). "Melatonin and its effects on plant systems," Molecules 23(9), 2352. DOI: 10.3390/molecules 23092352

Şimşek, Y. (1987). "Problems of quality seedling usage in afforestation," Journal of Forestry Research Institute 65, 5-29.

Tan, D. X., Hardeland, R., Manchester, L. C., Korkmaz, A., Ma, S., Rosales-Corral, S., and Reiter, R. J. (2012). "Functional roles of melatonin in plants, and perspectives in nutritional and agricultural science," Journal of Experimental Botany 63(2), 577-597. DOI: $10.1093 / \mathrm{jxb} / \mathrm{err} 256$

Taş, B. (2006). "Effects of geomorphological units on land Use in Tosya districts," Coğrafi Bilimler Dergisi 4 (1), 43-66.

Van-Tassel, D. L., and O'Neill, S. D. (2001a). "Putative regulatory molecules in plants: evaluating melatonin," Journal of Pineal Research 31, 1-7. DOI: 10.1034/j.1600079X.2001.310101.x

Van-Tassel, D. L., Roberts, N., Lewy, A., and O'Neil, S. D. (2001b). "Melatonin in plant organs," Journal of Pineal Research 31, 8-15. DOI: 10.1034/j.1600079X.2001.310102.x

Turk, H., and Erdal, S. (2015). "Melatonin alleviates cold-induced oxidative damage in maize seedlings by up-regulating mineral elements and enhancing antioxidant activity," Journal of Plant Nutrition and Soil Science (JPNSS) 178, 433-439. DOI: 10.1002/jpln.201400476

Wang, L., Zhao, Y., Reiter, R. J., He, C., Liu, G., Lei, Q., Zuo, B., Zheng, X. D., Li, Q., and Kong, J. (2014). "Changes in melatonin levels in transgenic 'micro-tom'tomato overexpressing ovine aanat and ovine hiomt genes," Journal of Pineal Research 56, 134-142. DOI: 10.1111/jpi.12105

Wang, Q., An, B., Wei, Y., Reiter, R. J., Shi, H., Luo, H., and He, C. (2016). "Melatonin regulates root meristem by repressing auxin synthesis and polar auxin transport in Arabidopsis," Frontiers in Plant Science 7, 1882.

Ye, T., Hao, Y. H., Yu, L., Shi, H., Reiter, R. J., and Feng, Y. Q. (2017). “A simple, rapid method for determination of melatonin in plant tissues by UPLC coupled with high resolution orbitrap mass spectrometry," Frontiers in Plant Science 8, 64. DOI: 10.3389/fpls.2017.00064

Yu, Y., Lv, Y., Shi, Y., Li, T., Chen, Y., Zhao, D., and Zhao, Z. (2018). “The role of phyto-melatonin and related metabolites in response to stress," Molecules (Basel, Switzerland), 23(8), 1887. DOI: 10.3390/molecules23081887

Yu, Y., Teng, Z., Mou, Z., Lv, Y., Li, T., Chen, S., Zhao, D., and Zhao, Z. (2021). "Melatonin confers heavy metal-induced tolerance by alleviating oxidative stress and reducing the heavy metal accumulation in Exophiala pisciphila, a dark septate endophyte (DSE)," BMC Microbiology 21, 40). DOI: 10.1186/s12866-021-02098-1

Zhang, N., Sun, Q., Zhang, H., Cao, Y., Weeda, S., Ren, S., and Guo, Y. D. (2015). "Roles of melatonin in abiotic stress resistance in plants," Journal of Experimental Botany 66(3), 647-656. DOI: 10.1093/jxb/eru336

Zhang, J., Zeng, B., Mao, Y., Kong, X., Wang, X., Yang, Y., Zhang, J., Xu, J., Rengel, Z., and Chen, Q. (2017). "Melatonin alleviates aluminium toxicity through 
modulating antioxidative enzymes and enhancing organic acid anion exudation in soybean," Functional Plant Biology 44(10), 961-968. DOI: 10.1071/FP17003

Zhang, R., Sun, Y., Liu, Z., Jin, W., and Sun, Y. (2017). "Effects of melatonin on seedling growth, mineral nutrition, and nitrogen metabolism in cucumber under nitrate stress," Journal of Pineal Research 62, E12403.

Article submitted: April 14, 2021; Peer-review completed: June 20, 2021; Revised version received and accepted: June 24, 2021; Published: July 1, 2021.

DOI: $10.15376 /$ biores.16.3.5706-5720 